\title{
31. A Alergia de Miss Hampton e as Luvas Cirúrgicas
}

\author{
Joffre Marcondes de Rezende
}

\section{SciELO Books / SciELO Livros / SciELO Libros}

REZENDE, J. M. A Alergia de Miss Hampton e as Luvas Cirúrgicas. In: À sombra do plátano: crônicas de história da medicina [online]. São Paulo: Editora Unifesp, 2009, pp. 263-264. História da Medicina series, vol. 2. ISBN 978-85-61673-63-5. https://doi.org/10.7476/9788561673635.0032.

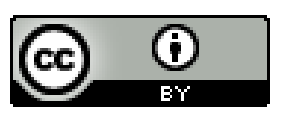

All the contents of this work, except where otherwise noted, is licensed under a Creative Commons Attribution 4.0 International license.

Todo o conteúdo deste trabalho, exceto quando houver ressalva, é publicado sob a licença Creative Commons Atribição 4.0.

Todo el contenido de esta obra, excepto donde se indique lo contrario, está bajo licencia de la licencia Creative Commons Reconocimento 4.0. 


\section{A Alergia de Miss Hampton e as Luvas Cirúrgicas*}

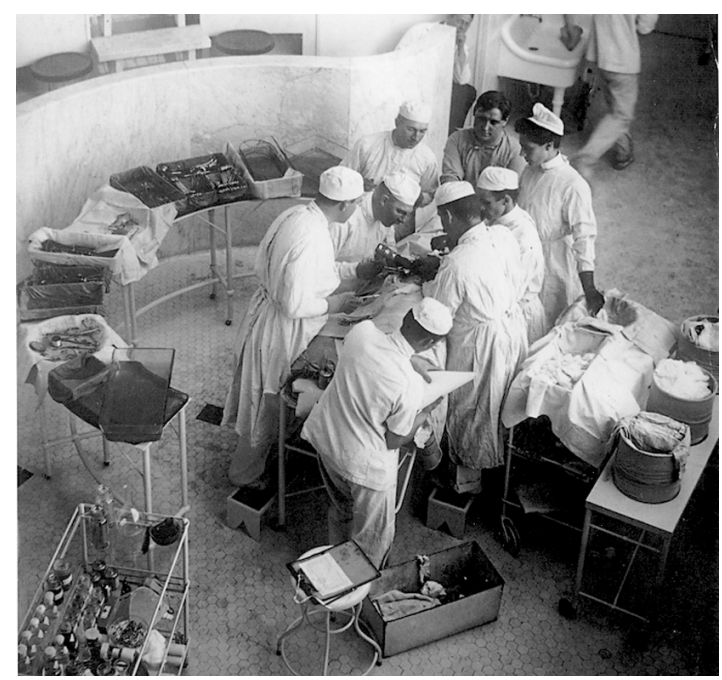

William Halsted durante uma operação.

uso das luvas cirúrgicas de borracha, em substituição às luvas de pano introduzidas por Mikulicz em I88I, teve início no Hospital Johns Hopkins, em I 890 .

O Hospital Johns Hopkins, em Baltimore, nos Estados Unidos, estava destinado a revolucionar o ensino e a prática da medicina. No ano de I 889 , quando abriu suas portas, o ensino médico achava-se desacreditado naquele país por seu baixo nível e pelas facilidades de se obter um diploma de médico.

O hospital foi especialmente construído para servir de base a um curso médico de alto padrão, no qual os professores seriam ao mesmo tempo os chefes dos departamentos correspondentes do hospital. Foram inicialmente escolhidos para essa dupla função William Welch, patologista, 34 anos; William Osler, clínico, 39 anos; William Halsted, cirurgião, 37; e Howard Kelly, ginecologista, 3 I anos. Coincidentemente três deles tinham o mesmo prenome: William.

* Publicado em Arquivos de Saúde Pública, 6, p. 50, 2006. 
O curso de graduação só teve início em I895 e a seleção dos alunos foi tão rigorosa que levou Osler a comentar com Welch: "Tivemos sorte de entrar como professores, porque seguramente não seríamos aceitos como alunos".

Os quatro jovens médicos modificaram radicalmente o ensino médico nos Estados Unidos. Como disse o próprio Welch: "Acabamos de vez com a ideia de que se pode formar um médico com a leitura de livros e preleções teóricas". Baltimore passou a ser a meca da medicina no início deste século (Major, I954, pp. 852-860).

Halsted era um cirurgião meticuloso e entusiasta dos métodos de antissepsia preconizados por Lister. Todos os integrantes de sua equipe cirúrgica, além de lavar, deveriam mergulhar as mãos em uma solução de ácido fênico antes das operações.

Sua enfermeira-chefe, miss Caroline Hampton, que o auxiliava na sala de operações, passou a apresentar dermatite nas mãos pela solução antisséptica. Em lugar de substituir sua auxiliar, Halsted decidiu encomendar à Goodyear um par de luvas de borracha delgada, de modo que ela pudesse, calçando as luvas, mergulhar as mãos na solução sem maiores consequências. Um dos assistentes de Halsted percebeu que a luva representava na realidade a melhor maneira de se obter a assepsia, porquanto poderia ser previamente esterilizada e propôs que todos na equipe passassem a usar luvas idênticas às de miss Hampton.

As luvas cirúrgicas de látex foram rapidamente adotadas em outros hospitais dos Estados Unidos e da Europa e tornaram-se parte do ritual cirúrgico desde então (Thorwald, s.d., pp. 3 IO-3 I 2).

A motivação e o interesse de Halsted por sua eficiente colaboradora, como ficou demonstrado, não eram apenas de ordem técnica. No dia 4 de julho de I890, um ano e meio após a inauguração do hospital, eles se casaram.

\section{Referências Bibliográficas}

Major, R. H. A History of Medicine. Oxford, Blackwell Scientific Publications, I954. Thorwald, J. O Século dos Cirurgiões. São Paulo, Boa Leitura Editora, s.d. 